\title{
Reindeer pastoralism in modern Siberia: research and survival during the time of crash
}

\author{
Igor Krupnik
}

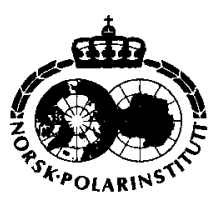

\begin{abstract}
In many areas across Siberia, the reindeer herding economy of the native people went into a deep recession during the post-Soviet transition of the 1990s. However, as a larger cross-section of data indicates, the reindeer stock decline is not a universal phenomenon. Nor is the present-day crisis in native Siberian herding economies an unprecedented event, as pastoralists did suffer tremendously in "traditional times", due to the devastating epizootics and other natural disasters, and even more so, during the Soviet-induced collectivization. While such a historical review by no means diminishes the scale of the present-day crisis in native herding economies, it helps to identify both the experience and traditional adaptations once used by the native Siberians during the previous times of hardship. Of those, the most efficient were: maintaining cultural and ecological diversity in local herding systems; the ability to shift quickly between nomadic and sedentary subsistence patterns; and preservation of the indigenous herding tradition and the "core" nomadic population as the invaluable source of cultural knowledge, technological expertise, and of domestic reindeer stock for ultimate recovery. The modern situation in Siberia, in fact, favours increased local diversity and helps to produce a steady stream of new "winners" as well as new "losers." This new experience has to be comprehensively documented, to produce both a reliable general overview and a detailed summary of the specific regional and local transitions.
\end{abstract}

I. Krupnik, Arctic Studies Center, Smithsonian Institution, Washington, D.C. 20560, USA.

Several recent surveys and first-hand reports indicate that the reindeer herding economy of Siberian indigenous people is in a deep recession if not in utmost crisis. Its very survival and continuity is reportedly threatened, due to severe economic hardships, demise of reindeer stock and lack of financial support from Russia's federal and local agencies. Herders and their families are abandoning the tundra and forest camps for villages, in search for any source of employment, health services as well as for the mere sense of belonging and stability. This process is amply documented across Siberia by native leaders, journalists, and visiting researchers alike (e.g. Ettyryntina \& Koryagin 1996; Abryutina 1997; Gray 1997; Startsev 1997; Williams 1997; Csonka 1998; Khrushchev \& Klokov 1998; Klokov 1998; Kladkin 1999; Vakhtin \& Krupnik 1999).

In many areas the situation can be properly labelled "The Great Reindeer Crash." While the entire reported domestic reindeer stock in Russia has dwindled from 22604000 in 1991 to barely 1592000 in 1997 (Khrushchev \& Klokov 1998: 13), many regions are in a true downward spiral. Chukotka (Chukchi Autonomous Area) witnessed its domestic reindeer stock slashed from 410000 to fewer than 180000 (Vedomost' 1996; Csonka 1998; Etylen 1999); the Sakha Republic (Yakutia - from 360000 to 200000 (Alexeev 1999); the Taimyr Area - from 120000 to 44000 (Klokov 1998). Several herding cooperatives, local communities, administrative districts, and whole indigenous nations, like the Ket and the Nganasan, have lost all or most of their reindeer husbandry (Vedomost' 1996; Khrushchev \& Klokov 1998; Klokov 1998). As reindeer stocks and its commercial production declined, supplies dried out. Herders' wages have not been paid in months and years, and the prices for major food commodities across the Russian Arctic skyrocketed (Ziker 
1998; Kladkin 1999). In most of the Siberian herding communities health service is almost nonexistent and violent death, alcoholism and other health risks are on the rise (Abryutina 1998; Gray 1998; Sukhaya 1999). In fact, the proceedings of this workshop, which aimed at producing a longterm research agenda for interdisciplinary studies in Siberian reindeer husbandry, may look more like a eulogy. This volume documents what was rightly called by Russian reindeer researcher Vitaly Zadorin (1999) "the beginning of the end of yet another branch of human civilization."

There is hardly an easy path toward designing an interdisciplinary and international "research planning" strategy under such harsh circumstances, from both logistical and ethical points of view. Research is clearly not the first priority to people and communities who are on the brink of survival. Therefore, any scientific study to be designed and accomplished under the current state of "crash" in Siberian reindeer industry has to deal with two basic imperatives. First, it should provide adequate documentation of the situation "on the ground" (whether catastrophic or not), from ecological and human perspective. And second, every local survey has to address (at least, implicitly) a critical moral question: is there any place or a strategy for Siberian reindeer herders of today to turn to in search of economic and cultural survival? I believe the situation may still be approached with a reserved optimism, particularly in certain areas, based upon the historical record of the endurance and adaptability of the Siberian indigenous people.

\section{Indigenous reindeer economies in Siberia}

Traditionally, native subsistence economies across the Russian Arctic and Siberia were arranged under some sort of nomadic-sedentary continuum. It supported an amazing diversity in northern lifestyles, cultural patterns and modes of resource utilization (see Krupnik 1989, 1993: 210-215). The two opposing extremes of the spectrum were created by sharply contrasting subsistence strategies in terms of their type of procurement and responses to the environmental change. The sedentary strategy was orientated toward intense exploitation of relatively small selected coastal and riverine niches, with high and usually predictable local concentrations of many valuable subsistence resources. The contrasting mobile/ nomadic strategy followed a pattern of population dispersion and regular rotation of seasonal hunting ranges and/or reindeer pastures. It allowed to occupy much larger environmental niches, where subsistence resources were patchy, unstable or of short duration in course of the annual cycle.

Most of the indigenous nations that are at the focus of this volume have adopted the latter strategy of year-round mobile/nomadic subsistence, with domestic reindeer or caribou as its prime resource. This, again, included a whole spectrum of ecological and/or cultural patterns based upon the growing role of domesticated (that is, herded) versus wild or feral (that is, hunted) races of $R$. tarandus in human economy. At the one end, there were native groups like the Iñupiat, Innu, Dogrib and Gwich'in in North America that never developed reindeer husbandry and lived primarily by highly specialized exploitation of mobile caribou stocks. Most of the tundra and the boreal forest zone in Siberia was occupied by indigenous nations that matched subsistence caribou hunting with small-scale reindeer economy (like the Nganasan, Dolgan, Yukagir, Evenk, Even, Ket, Orok and Khanty peoples). Finally, there were true pastoralists, such as the "European" and Siberian Nenets, Chukchi, Koryak, Komi and the Saami, who developed highly sophisticated and specialized reindeer industries, wherein hunting played a little role - if any - in the domestic economy. This typology, of course, refers to the time prior to the state-induced policies of economic modernization in Siberia, Scandinavia and North America alike.

Such subsistence diversity was reportedly a product of successful cultural adjustment to the high insecurity and general resource instability of the Arctic environment (Krupnik 1993: 156-159). In fact, dozens of local subsistence patterns were positioned in between the two extremes of the "Arctic cultural continuum": the nomadic and the sedentary. This was determined by every local group's range of annual mobility, distance to be covered each year and/or the number of people dependent upon reindeer/caribou as their staple economic resource. Differences in residential mobility even among the nearby communities were well established and persistently maintained, both culturally and ecologically (for regional surveys see Charnolusskii 1930; Druri 1936; Vasil'ev 1970). Increase as well as decrease in 
nomadism was widely practised as an adaptive response to changing wealth in domestic reindeer stock and/or shifts in local subsistence resources. Residential mobility was also affected by dominant environmental trends that could bring hard times alternatively either to inland herders and caribou hunters or to the coastal whalers, sealhunters, and fishermen (Minc 1986: 70; Krupnik 1993: 210-212).

Human life in the Arctic - as it is known from elders' memories, archaeological and historical records - has been always dominated by periodic or irregular ecosystem changes. These were triggered by the alternating warming and cooling phases, occasional weather catastrophes, by game population cycles and epizootics. Thus, the ongoing flux of Arctic native residents from a (more) sedentary to (more) nomadic subsistence and vice versa was the key factor of strength and sustainability in native economies. This amazing level of cultural and ecological diversity required flexibility and endurance during hard times. Both features are indeed amply documented by elders' memories as well as by numerous ethnographic and archaeological records across the Arctic (Krupnik 1993: 210-215).

\section{Cases of earlier reindeer catastrophes}

As we know from Russian historical sources, terrible things have happened many a time to Siberian indigenous hunters and herders. Records of the 1800 s and the early 1900 s have documented devastating losses of reindeer stocks by local herders, due to the occasional weather and environmental calamities, and striking epizootics. According to numerous observers, those produced panic and were met with dreadful horror by local herders. Wealthy pastoralists could be converted into herdless, sedentary paupers in a matter of days. As one witness reported, "During epizootics, reindeer die throughout the tundra in herds of thousands. Enormous graveyards appear, cavernous places infected with a terrible disease ... The herders are in a panic, and are changed overnight from wealthy people to beggars. They ride away from the dead herd on the few animals left standing on their feet, just to keep them alive" (Sosunov 1925: 35 in Krupnik 1993: 153-154, M. Levenson trans.).

The Soviet-induced modernization of the Siber- ian indigenous peoples and their economies triggered an even more profound and dramatic transition after 1930. The new regime espoused the ideology of collective property and labour, and it favoured rapid sedentarization - by force, if necessary - of the nomadic population. It eliminated rich herders, discouraged year-round mobility, and launched a full-scale policy of active social engineering by closing smaller villages and family nomadic camps (Forsyth 1992: 293-299; Vakhtin 1994: 50-51). Owners of large and medium-size herds were labelled "class enemies." They were deliberately overtaxed, disenfranchised, forced to join collective farms, and jailed or exiled when they refused. The herders resisted by fleeing to the remotest tundra areas where they could escape the iron fist of the Soviet regime. When they were unable to flee they preferred to slaughter their livestock rather than seeing them incorporated into collective herds. Among the reindeer herders of northern Siberia, the estimated loss of stock by 1935 was between 30 and $50 \%$, or from 2200000 to less than 1500000 reindeer (Forsyth 1989; Khrushchev \& Klokov 1998: 7-9). This was reportedly close to or even higher than the present-day reindeer crash. The Central Siberian cattle and horse pastoralists, such as Sakha and Buryat, had slaughtered about $60 \%$ of their stock (Chichlo 1981). The remaining domestic stock was then incorporated as a common property of the state-supported collective farms (kolkhozes) and state farms (sovkhozes).

Following the state-run resettlement and sedentarization campaign, hundreds of smaller sites and family camps were closed; their inhabitants were forcefully relocated to larger villages or newly built modern communities. Former herding camps of close relatives and long-term partners were converted into "productive brigades" (work teams), with appointed migration routes, fixed salaries, and annual production output set up by the local farm and district economic bosses. By the 1970s, the pre-Soviet free mobility of herders and their former nomadic lifestyle was almost gone under the pressure of paternalistic Soviet modernization. This caused a tremendous shift of the once nomadic population - primarily women, children and elders - towards sedentary village life and the wage/welfare economy. A few limited areas across Siberia, such as the Yamal and the Gydan Peninsulas, the upper Kara River basin, offered rare exceptions, remaining as prime "sanctuaries" of more traditional-style family 
herding (Bjørklund 1995; Golovnev 1995; Yoshida 1997; Golovnev \& Osherenko 1999). Native reindeer pastoralism was declared an "archaic" and hazardous occupation, "unhealthy" for women and children, and "doomed" to be replaced by more advanced practices. Tons of the former Soviet propaganda literature as well as of academic research worked to disseminate this message of blunt pressure unleashed by a powerful state against cultural traditions of its remote indigenous communities. These sad memories are often overlooked against the background of post-Soviet nostalgia (even by the native people themselves, e.g. Ziker 1998: 195-196, 214; Kladkin 1999: 9-11). The true "costs-and-benefits" record has to be remembered for a more balanced perspective on the endurance of indigenous herding under the Soviet regime.

\section{Herders' survival strategies during the crash}

This historical review by no means diminishes the scale of present-day misfortunes, nor is it aimed at overlooking the dismal status of indigenous reindeer economies in Siberia. It helps, however, to illuminate both the experience and the resources once used by the Siberian native herders in times of hardship. Those may be of critical value for the tarandus users of today.

One of the most successful traditional adaptive strategies was the remarkable diversity of the northern human-reindeer systems, both cultural and ecological. The Soviet state had almost succeeded in replacing this diversity by a more or less uniform herding pattern spread over the entire tundra zone of Arctic Russia, from the Barents Sea to the Bering Sea. It introduced large-scale, heavily subsidized, collectivized, and centrally planned reindeer industry, and it promoted this model with an iron fist. The model was based on the stateallocated and prescribed local distribution of seasonal pastures and migration routes. It favoured similar practices and it used an almost uniform ratio of some 6-8 paid herders for a standard "brigade" (herding crew) in charge of a stock of 2000-2500 reindeer. This greatly diminished diversity was one of the heaviest costs of the governmental intervention into the once "unregulated" subsistence economy. Generations of local experiences, skills and cultural adaptations were ignored.
Recent indigenous revival in Siberia followed by the collapse of the centralized state economy in 1991-92 has, surprisingly, opened opportunities for more diversity in native reindeer herding systems, at least in certain areas. Planned production quotas have been abandoned. Few if any mechanisms of enforcement - to keep native herders within the strict designated slots of seasonal pastures and migration routes once assigned by the state agencies - remain in place. Since the late 1980s, major limitations on mobility and residence in tundra and boreal forest pasturelands were lifted, first and foremost for women and children who follow professional herdsmen and hunters, primarily during the summer months. This increased mobility and growing regional diversity could offer a fortuitous lift to native reindeer economies during the ongoing crash.

The long-expected transformation of the postSoviet reindeer industry has fostered enthusiasm in native communities, though hopes have been shortlived. The drive to decentralize or even to close the state herding farms and to reclaim reindeer property through privatization and various forms of shared ownership became extremely popular. For a few years, native leaders and local media across Siberia engaged in public debates focused upon small reindeer cooperatives or family-based teams of herders ("family farms"). Whichever new herding and property system eventually emerges across Siberia, it will most certainly help to return women, children and elders to reindeer camps on a more permanent basis - as is already happening in Yamal, the Lower Yenisey River valley, the Northern Urals, and some other areas (see Bjørklund 1995; Klokov 1996; Golovnev \& Osherenko 1999). Those who are to come back to the tundra will need more reindeer to become more self sufficient. This renewed focus on reindeer as a foundation for family life and a means of survival rather than a "commodity" under a state-controlled economy may be another resource to boost herders' endurance during the crash.

Last but not least is the new role of the nativist grass-roots ideology that has growing influence across Siberia. Native (that is, traditional or "our fathers") values of a free life outside the settlements dominated by the outsiders and frustrated by alcoholism, unemployment and violence, have gained a renewed popularity. Participation in subsistence activities and residence in tundra camps is coming back as the pillars of cultural continuity and ethnic pride. 
As a result of these and many other factors, a sort of a regeneration of mobile subsistence or of mixed subsistence and commercial reindeer herding is gradually taking place in certain areas in Siberia. This is sure to transform into a greater diversity in the local herding systems (see reviews in Anderson 1995; Klokov 1996, 1998). While most data are still incidental, this process is of critical importance and requires special research attention and thorough statistical documentation. To the best of our knowledge, the Yamal, Gydan, and the lower Yenisey River valley as well as the northern sections of the Sakha Republic (Yakutia) have the best chances to brave the calamities of the "Big Crash." Local survival is almost certain to be pursued via a gradual (though highly uneven) shift toward family herding and more active "bush life," after decades of state engineering and enforced sedentarization.

In several other regions the old reindeer economy of the Soviet era all but collapsed and the reindeer stock is at its lowest level on record. Chukotka (Chukchi Autonomous Area) is probably the hardest hit, followed by the Taymyr Peninsula and Evenkia (Evenki Autonomous Area; see Gray 1997; Startsev 1997; Klokov 1998; Ziker 1998). Here both state-owned and cooperative herds have degenerated because of poor management, poaching and direct neglect by the herders. While local people experience enormous suffering and cultural loss, the process, again, follows a fairly traditional pattern: a rapid shift to a sedentary (village) lifestyle under emergency conditions in the tundra. Sedentarization may be a dreadful option; but if history is a guide then both people and reindeer may eventually return to tundra pastures when the situation improves. The old nomadic-sedentary continuum is once again offering options to optimize local economic activities and redistribute the population. This time, however, the shift toward sedentariness can hardly be called a response to environmental change but a more desperate survival strategy during an era of extreme economic instability and social deprivation.

\section{Research agenda during the "time of crash"}

The present-day crisis in the Siberian reindeer economy poses tough ethical challenges for social and natural scientists alike. The current dismal status of herders and their stocks - widespread pasture degradation, painful transition to the new "sedentism," and the endangered legacy of the Siberian "reindeer herding civilization" - have to be amply documented if native cultural endurance and/or scholarship are to offer a plausible solution.

For a few short years in the early 1990s many a regional Siberian administration allowed tourists and other visitors almost unrestricted travel in native areas, including distant reindeer camps and herds. Many researchers and journalists, western and Russian alike, have enjoyed a unique experience of long-term contact with and sojourn among native herders, often in some of the most remote and once inaccessible places across Siberia (Vitebsky 1992; Kwon 1993; Bjørklund 1995; Anderson 1996; Kerttula 1996; Yoshida 1997; Fondahl 1998; Gray 1998; Takakura 1998; Tuisku 1998; Ziker 1998; Golovnev \& Osherenko 1999). The bulk of our current knowledge on Siberian herding communities presently comes from these foreign or joint studies rather than from the Soviet ethnographies of that bygone era.

While more local studies of the Siberian herding communities are currently available than ever before, one of the most urgent tasks is to produce a reliable overview of the overall status of the Siberian reindeer economies, something like a "State of the Industry" report. A similar strategy was once advanced by the respected (Soviet) "Committee on the North" in the 1920s, when native Siberian herders experienced even more dreadful hardships as a result of the Russian Revolution, Civil War, and overall economic collapse (Sergeev 1955: 224-228). The committee's determination generated a year-round inventory, the Economic census of the polar North of 1926/27 (Pokhoziaistvennaia perepis' 1929), that produced a unique database on almost every aspect of native subsistence activities. Today, a similar overview can be produced by compiling available local reports or by an overall Russian "Arctic Reindeer Project" built of successive regional surveys in a common format. Russian researchers argue in favour of both types of studies (e.g. Klokov 1998), and they sure may capitalize on their excellent long-term experience and intellectual resources. Funding, though, is a key factor; hence these efforts deserve strong encouragement from and practical support by the international research community.

Second, ample documentation of specific re- 
gional and local transitions remains a high priority. The re-emerging regional and cultural diversity in Siberian reindeer economies produces a steady stream of new "winners" as well as new "losers." It is still hard to rationalize why - under generally similar political and economic systems the Chukchi are progressively losing reindeer while the Nenets steadily increase their private herds, often to an extent dangerous to the ecosystem and therefore to their herding. Both types of transition as well as dozens of other local experiences may prove instructive to reindeer managers, native leaders and indigenous users anxious to test opportunities in their local areas. This set of regional case studies, again, looks like a replica of the research once undertaken in the 1930s under the All-Union programme of the Arctic Pastureland Inventory and Redistribution (Zemel'no-pastbishchnoe ustroistvo). The reports were duly put out as local publications and in a serial named The Soviet Reindeer Industry (Sovetskoe Olenevodstvo, 1932-37). Today a similar series may be endorsed or even co-sponsored by the recently established Russian Reindeer-Herders Union (Soyuz olenevodov Rossii), obviously a primary potential user of such information.

Third, the present situation is highly different from the previously documented reindeer crashes in Siberia in that the decline in domestic stock is matched (or is followed) by a dramatic increase in stocks of wild and feral reindeer (e.g. Chernyavskii \& Kretchmar 1998). This opens a whole new spectrum of issues, such as competition and interaction between domestic and wild reindeer in the same (or similar) eco-niches. Feral and wild reindeer stocks also offer new hazards as well as new subsistence resources for herders and native communities in general. For decades, these issues were of low priority for scientists and users alike almost everywhere in the Russian Arctic, except for the Taimyr Peninsula, northern Sakha (Yakutia), Wrangel Island and a few other places. Today, the interaction between feral and domestic reindeer may well be listed as one of the most urgent issues for both natural and social scientists engaged in Siberian research. Here, North American scholars could make invaluable contributions based on their experience in addressing the issues of co-management of caribou (wild reindeer) populations, control over high-tech poaching by outsiders, and prospects for tourist caribou hunting in Siberia.

Last but not least is the issue of cultural continuity of the Siberian "reindeer civilization." As more people are forced out of herding camps by economic hardship and management failures, the pool of traditional subsistence knowledge, practical skills, grazing and pasture experts, and trained stock users is shrinking. The only way to keep this legacy alive is to increase its public status as an invaluable subsistence resource and an irreplaceable cultural and public treasure. Here, once again, scholars may offer critical help. Flagging public spirit and herders' pride can be boosted via outreach and exhibit programmes, publication of elders' narratives, historical photographs, catalogues and classical ethnographies addressed primarily to local audiences (e.g. Alexeev 1993; Etylen 1996; Krupnik \& Narinskaya 1998; Pika 1998). Modern research by international teams of tarandus and Arctic pasture specialists offers an excellent path to document traditional techniques, skills, and practices that are still in use by native herders across Siberia. If matched with energetic outreach and dissemination, it could make a critical breakthrough in public acknowledgement of the value of the "Siberian reindeer civilization" - in the same way recent caribou studies in North America have advanced the standing of Native American users' traditional ecological knowledge. The thriving though clearly endangered - legacy of native pastoralist culture and nomadic lifeways in Siberia has to be captured, promoted and re-conveyed to northern residents to ensure its continuity and survival in the Russian Arctic.

\section{References}

Abryutina, L. I. 1997: Narody Severa. Problemy, analiz prichin i perspektivy ikh preodoleniia. (Peoples of the [Russian] North. Problems, their causes and prospects for solution.) Paper presented at the Constructing Cultures Then and Now Conference. New York, 13-17 November 1997.

Abryutina, L. I. 1998: Kratkaia kharakteristika medikosotsial'nykh problem korennykh malochislennykh narodov Chukotki. (Medical and social problems of the native minorities of Chukotka: a brief summary.) Paper Presented at the 3rd Congress of the International Association of Arctic Social Scientists. Copenhagen, 21-23 May 1998.

Alexeev, A. A. 1993: Zahytyi mir predkov. Ocherki traditsionnogo mirovozzreniia evenov severo-zapadnogo Verkhoiania. (The forgotten universe of our ancestors. Traditional beliefs of the Even of north-western Verkhoyansk Region.) Yakutsk: Sitim.

Alexeev, A. A. 1999: The system of reindeer husbandry under modern conditions in the Republic of Sakha/Yakutia and the ways out of crisis. Paper presented at the International 
Workshop, the Human Role in Reindeer/Caribou Systems. Rovaniemi, 10-14 February 1999.

Anderson, D. G. 1995: The aboriginal people of the Lower Yenisey Valley: an ethnographic overview of recent political developments in north central Siberia. Pol. Geogr. 19(3), 184-218.

Anderson, D. G. 1996: National identity and belonging in Arctic Siberia: an ethnography. Evenkis and Dolgans of Khantaiskoe Ozero in the Taimyr Autonomous District. Ph.D. thesis, University of Cambridge.

Bjørklund, I. 1995: A journey to the Bolshezemelskaja tundra. In I. Bjørklund et al. (eds.): The Barents Region. Pp. 71-80. Tromsø: Tromsø Museum.

Charnolusskii, V. V. 1930: Materialy po bytu loparei. Opyt opredeleniia kochevogo sostoianiia loparei vostochnoi chast Kol'skogo poluostrova. (Data on the daily life of the Lapps: an attempt to estimate the state of nomadism among the Lapps of the eastern Kola Peninsula.) Leningrad: Russkoe geograficheskoe obshchestvo (Russian Geographical Soc.).

Chernyavskii, F. B. \& Kretchmar, M. A. 1998: Wild reindeer Rangifer tarandus (L.) in Chukotka. Rangifer $18(\dot{3}-4), 127-$ 132.

Chichlo, B. 1981: La collectivisation en Sibérie: un problème de nationalités. (Collectivization in Siberia: the ethnic problem.) In: L'expérience soviétique et le problème nationale dans le monde (1920-1939). Vol. 1. (The Soviet experience and world nationality problems [1920-1939]. Vol. 1.) Pp. 279-307. Paris: Langues.

Csonka, Y. 1998: La Tchoukotka. Une illustration de la question autochtone en Russie. (Chukotka. An illustration of the indigenous issue in Russia.) Rech. Amérindiennes au Québec 28(1), 23-41

Druri, I. V. 1936: Pastbishchnoe khoziaistvo i vypas olenei u chukoch Anadyrskogo raiona. (Pasture economy and reindeer herding among the Chukchi of the Anadyr District.) Trudy Arkticheskogo instituta 62, 105-124. Moscow.

Etylen, V. M. 1996: Chukchi. (The Chukchi.) In I. Krupnik (ed.) and V. Chaussonnet (compiler): Perekrestki kontinentov. Kul'tury korennykh narodov Dal'nego Vostoka i Aliaski. (Crossroads of continents. Cultures of indigenous peoples of the [Russian] Far East and Alaska.) Pp. 20-21. Washington and Moscow: Smithsonian Institution and Institute of Cultural Heritage of Russia.

Etylen, V. M. 1999: What kind of a crisis can reindeer herding in Chukotka endure? Paper presented at the International Workshop, the Human Role in Reindeer/Caribou Systems. Rovaniemi, 10-14 February 1999.

Ettyryntina, M. \& Koryagin, A. 1996: To live or to die? In A. Pika, J. Dahl \& I. Larsen (eds.): Anxious North: indigenous peoples in Soviet and post-Soviet Russia. IWGIA Document 82, 227-231. Copenhagen.

Fondahl, G. 1998: Gaining ground? Evenkis, land, and reform in southeastern Siberia. Needham Heights, MA: Allyn \& Bacon.

Forsyth, J. 1989: The indigenous peoples of Siberia in the Twentieth century. In A. Wood \& R. A. French (eds.): The development of Siberia. Pp. 72-95. New York: St. Martin's Press.

Forsyth, J. 1992: A history of the peoples of Siberia: Russia's North Asian colony, 1581-1990. Cambridge: Cambridge University Press.

Golovnev, A. V. 1995: Govoriashchie kul'tury. Traditsii samoditsev i ugrov. (Talking cultures. Traditions of the
Samoyedic and Ugrian peoples.) Ekaterinburg: Russian Academy of Sciences.

Golovnev, A. V. \& Osherenko, G. 1999: Siberian survival: the Nenets and their story. London: Cornell University Press.

Gray, P. A. 1997: Snezhnoe, where East and West collide. Transitions: Changes in Post-Communist Societies 4(6), 96100.

Gray, P. A. 1998: Pursuing a Native movement in a Russian space: the predicament of indigenous peoples in post-Soviet Chukotka. Ph.D. thesis, University of Wisconsin.

Kerttula, A. M. 1996: Antler on the sea: Chukchi, Yupik, and Newcomers in the Soviet North. Ph.D. thesis, University of Michigan.

Khrushchev, S. A. \& Klokov, K. B. 1998: Nenetskoe olenevodstvo: podkhody $k$ razrabotke kontseptsii ustoichivogo razvitiia. (The Nenets reindeer industry: a strategy for sustainable development.) Etnogeograficheskie i etnoekologicheskie issledovanita (Ethnogr. Ethnol. Stud.) 7. St. Petersburg.

Kladkin, V. M. 1999: Sovremennye problemy olenevodcheskogo khoziaistva. (Modern problems in reindeer industry.) Nauka-olenevodstvu (Information Bull.) 1, 9-13. Yakutsk.

Klokov, K. B. 1996: Kochevoe olenevodcheskoe naselenie: otsenka vozmozhnostei etnosotsial'noi adaptatsii i razvitia. (The nomadic reindeer herders: prospects for ethno-social adaptation and development.) Etnogeograficheskie issledovaniia (Ethnogeogr. Stud.) 1. St. Petersburg.

Klokov, K. B. 1998: Traditsionnoe prirodopol'zovanie korennykh malochislennykh narodov Severa: geograficheskie $i$ sotsial'no-ekologicheskie aspekty problemy). (Traditional land use system of the indigenous northern minority peoples. geographical and socio-ecological aspects.) Doctorat diss. summary (Avtoreferat), Institute of Geography, Russian Academy of Sciences.

Krupnik, I. 1989: Arkticheskaia etnoekologiia. Modeli traditisionnogo prirodopol'zovaniia morskikh okhotnikov i olenevodov Severnoi Evrazii. (Arctic ethno-ecology. Models of traditional subsistence of marine hunters and reindeer herders of northern Eurasia.) Moscow: Nauka Publ.

Krupnik 1. 1993: Arctic adaptations. Whalers and reindeer herders of northern Eurasia. London: University Press of New England.

Krupnik, I. \& Narinskaya, N. E. (eds.) 1998: Zhivoi Yamal/ Living Yamal. Exhibit catalog. Moscow: Sovetskii Sport.

Kwon, H. 1993: Maps and actions: nomadic and sedentary space in a Siberian reindeer farm. $\mathrm{PhD}$ thesis, University of Cambridge.

Minc, L. D. 1986: Scarcity and survival: the role of oral tradition in mediating subsistence crises. J. Anthropol. Archaeol. 5, $39-113$.

Pika, T. I. (ed.) 1998: Zemlia Yamal. Albom Yamal'skikh ekspeditsii V.P. Evladova/The land of Yamal. Catalogue of V. Evladov's Yamal expedition. Moscow: Sovetskii Sport.

Pokhoziaistvennaia perepis' Pripoliarnogo Severa SSSR 1926 1927 g. Territorial'nye i gruppovye itogi perepisi. (Economic census of the polar North of the USSR, 1926-1927. Area and group Data.) 1929. Moscow: Statizdat.

Sergeev, M. A. 1955: Nekapitalisticheskii put' razvitiia malykh narodov Severa. (Non-capitalist path of development of the small-numbered peoples of the North.) Trudy Instituta etnografii AN SSSR (Proc. Inst. Ethnogr. USSR Acad. Sci.) 27. Moscow.

Sosunov, P. I. 1925: Tobol'skii Sever. (Northern areas of the Tobolsk Province.) Severnaia Aziia 3-4. Leningrad 
Startsev, B. 1997: Doroga v nikuda. Korennym narodam Chukotki ne vyzhit' bez gosudartsvennoi podderzhki. (The route to nowhere. Native people of Chukotka cannot survive without state support.) Itogi 3, 56-61. Moscow.

Sukhaya, S. 1999: Sindrom poliarnogo napriazheniia. (Polar stress syndrome.) Trud 28(23253), 1-2. Moscow.

Takakura, H. 1998: Reorganization of the reindeer industry under de-Sovietization; a transformation of a Soviet village community in northern Yakutia, Siberia. (In Japanese, with English summary.) Jpn. J. Ethnol. 63(1), 19-43.

Tuisku, T. 1998: A traditional livelihood in the 1990s - a case study of Nenets reindeer herding in north-west Russia. Paper Presented at the 3 rd Congress of the International Association of Arctic Social Scientists. Copenhagen, 21-23 May 1998.

Vakhtin, N. B. 1994: Native peoples of the Russian Far North. In: Polar peoples. Self-determination and development. Pp. 29-80. London: Minority Rights Group. (Originally publ. 1992.)

Vakhtin. N. \& Krupnik, I. 1999: Power, politics, and heritage: undercurrent transformation in the post-Soviet Arctic - the case of Chukotka. In F. Sejersen (ed.): Changes in the circumpolar North. Culture, ethics, and self-determination. Topics in Arctic Social Sciences 3, 27-42. Copenhagen: IASSA.

Vasil'ev, V. I. 1970: Nentsy i entsy Taimyrskogo natsional'nogo okruga. Ocherk khoziajstva, byta i etnicheskikh protsessov, protekayushchikh na Eniseiskom Severe. (The Nenets and Enets people of the Taimyr National Area.
Economy, daily life, and ethnic processes of the northern Yenisey River Region.) In B. O. Dolgikh \& I. S. Gurvich (eds.): Preobrazovaniia v khoziaistve i kul'ture i etnicheskie protsessy u narodov Severa. (Economic and cuitural transformation, and ethnic processes among the peoples of the North.) Pp. 106-163. Moscow: Nauka Publ.

Vedomost' dvizheniia pogolov'ia po sovkhozam okruga. (Reindeer stock change by state farms. General statistical sheet, 1980-1995) 1996. Anadyr: Area Office of Agriculture.

Vitebsky, P. 1992: Landscape and self-determination among the Eveny. The political environment of Siberian reindeerherders today. In E. Croll \& D. Parkin (eds.). Bush base: forest farm. Culture, environment, and development. Pp. 223 246. London: Routledge.

Williams, D. 1997: Creating a hot property in Siberia is every bit as hard as it sounds. The Washington Post Oct. 3, A29, A34.

Yoshida, A. 1997: Kul'tura pitania gydanskikh nentsev: interpretatsiia $i$ sotsial naia adaptatsiia. (Culture of food consumption of the Gydan Nenets: interpretation and social adaptation). Moscow: Institute of Ethnology.

Zadorin, V.I . 1999: The beginning of the end of yet another branch of human civilization. Paper presented at the International Workshop, the Human Role in Reindeer/ Caribou Systems. Rovaniemi, 10-14 February 1999.

Ziker, J. P. 1998: Kinship and exchange among the Dolgan and Nganasan of northern Siberia. Res. Econ. Anthropol. 19, 191238. 